Muséologies

Les cahiers d'études supérieures

muséologies

\title{
Embodied Dialogue: Group Learning and Collaboration at DHC/ART Foundation for Contemporary Art
}

\section{DHC/ART}

Volume 9, numéro 1, 2018

Monde des Arts / Arts des mondes

URI : https://id.erudit.org/iderudit/1052632ar

DOI : https://doi.org/10.7202/1052632ar

Aller au sommaire du numéro

Éditeur(s)

Association Québécoise de Promotion des Recherches Étudiantes en

Muséologie (AQPREM)

ISSN

1718-5181 (imprimé)

1929-7815 (numérique)

Découvrir la revue

Citer ce compte rendu

DHC/ART (2018). Compte rendu de [Embodied Dialogue: Group Learning and

Collaboration at DHC/ART Foundation for Contemporary Art]. Muséologies,

9(1), 135-160. https://doi.org/10.7202/1052632ar

Tous droits réservés (C Association Québécoise de Promotion des Recherches Étudiantes en Muséologie (AQPREM), 2018
Ce document est protégé par la loi sur le droit d'auteur. L’utilisation des services d’Érudit (y compris la reproduction) est assujettie à sa politique d'utilisation que vous pouvez consulter en ligne.

https://apropos.erudit.org/fr/usagers/politique-dutilisation/ 
Carnet deux

Embodied Dialogue: Group Learning and Collaboration at DHC/ART

Foundation for Contemporary Art

DHC/ART 
Amanda Beattie is a co-coordinator of the Education Department at DHC/ART Foundation for Contemporary Art, as well as an Art History teacher at Dawson College. Amanda has a Master's degree in Art History, and a background in museum education from various institutions including the Peggy Guggenheim Collection and the Biennale di Venezia (Venice), The Museum of Modern Art (New York), as well as The Montreal Museum of Fine Arts and the Centre international d'art contemporain de Montréal. Amanda has also worked as a consultant, writing for catalogues and developing pedagogical tools for various arts organizations.

Pohanna Pyne Feinberg is an artist-educator. Her work is generated by curiosity, enchantment, textures of impermanence, the resonance of collective memory, and acts of compassion. Her art practice takes the form of community co-creations, participatory audio walks, mixed media installations, and walk-based collaborations with the environment. Pohanna teaches art history at Dawson College and has designed education programs for contemporary art exhibitions such as the international biennale Le Mois de la Photo à Montréal and in collaboration with the DHC/ART Education team. In 2011, she received a Masters degree in Art History from Concordia University, where she continued her research and is currently a doctoral candidate in Art Education.

Daniel Fiset est historien de l'art et éducateur. Depuis 2011, il est un des coordonnateurs de DHC/ART Éducation, en plus de terminer un doctorat en histoire de l'art sous la supervision de Suzanne Paquet à l'Université de Montréal. Ses recherches portent sur les liens entre la culture visuelle contemporaine et les pratiques 
photographiques en art actuel, qu'il analyse par le biais des études technologiques et médiales. Il a développé depuis plusieurs années une expertise dans les domaines de l'éducation muséale, de la programmation culturelle et du commissariat en collaboration avec divers organismes québécois, tels que l'Université de Montréal, le Musée des beaux-arts de Montréal, et OPTICA. Ses recherches ont été présentées au Canada comme à l'étranger et il a collaboré à titre d'auteur à plusieurs publications en art actuel.

Emily Keenlyside has worked in art museums, galleries, artist-run centres, and feminist community organizations for two decades. From 2012-2017 she co-coordinated Education at DHC/ART Foundation for Contemporary Art and is currently pursuing a PhD in Art Education at Concordia University. Emily designed and delivers a skill-based, bilingual training program for new guides at the Montreal Museum of Fine Arts, and has trained museum guides in Canada and the US to engage visitors in group dialogue. Her action research focuses on workplace learning, critical museum pedagogies, and the politics of reflexivity and discomfort in art museums. Emily's written work has been published in the Canadian Review of Art Education and Studies in Art Education.

Marie-Hélène Lemaire est co-coordonnatrice du département éducatif de DHC/ART Fondation pour l'art contemporain. Elle travaille également à la programmation éducative des expositions de réalité virtuelle et d'art immersif au Centre Phi. Auparavant, elle a travaillé au Musée d'art contemporain de Montréal et à la Galerie Leonard and Bina Ellen de l'Université Concordia. Avec un baccalauréat en littérature et une maîtrise en muséologie, elle a obtenu son doctorat en communications de 
l'Université Concordia en 2015. Ses recherches portent sur la manière dont les participants à la visite de groupe interprètent en dialogue, de manière improvisée, et par l'entremise de leur corps en mouvement, les ouvres d'art contemporain dans l'espace d'exposition. Elle a présenté ses recherches à diverses conférences nationales et internationales et ses écrits sur l'interprétation de l'art contemporain ont été publiés, entre autres, dans WI: Journal of Mobile Media et ESPACE art actuel. 
As DHC/ART Foundation for Contemporary Art approached its 10th anniversary, its Education department-Amanda Beattie, Daniel Fiset, Emily Keenlyside, and Marie-Hélène Lemaire—sat down with artist-researcher-educator Pohanna Pyne Feinberg to discuss their work.

This one-time forum examined the particularities of their educational approach through a critical reflection on the past, present, and future of their work as gallery educators at DHC/ART, a parcours which began at the end of 2011. The following exchange highlights shared values grounding the Foundation's mandate, demonstrates the relationship between their work methodology and their mediation work in the galleries, and unpacks certain key concepts that shape their work.

Cette conversation s'inscrit dans le cadre d'un partenariat que DHC/ ART Éducation entretient avec des chercheurs universitaires autour des concepts de pensée en marche, de visite dé-guidée et d'indiscipline. En mai 2015, les éducateurs de DHC/ART ont été invités par Dominic Hardy (Histoire de l'art, UQAM) et Myriam Suchet (actuellement responsable du Centre d'études québécoises à l'Université de Paris III-Nouvelle Sorbonne et anciennement titulaire de la Chaire d'études de la France contemporaine à l'Université de Montréal) à effectuer une journée de pensée en marche de l'exposition Pièces de résistance de Yinka Shonibare MBE (DHC/ART, 29/04/15-20/09/15) dans le cadre de leur série de Rencontres indisciplinaires. La " pensée en marche", selon Suchet, c'est la recherche qui sort de l'institution universitaire pour venir au musée, ce qui dynamise la réflexion théorique en dissertant avec l'œuvre plutôt que sur l'œuvre'. Le format de la visite consiste à faire intervenir plusieurs chercheurs de différentes disciplines dans les espaces d'exposition du musée en présence d'un médiateur qui facilite les échanges avec le public. Nous proposons de réfléchir à Pièces de résistance de Yinka Shonibare MBE par l'entremise de trois études de cas tirées de la rencontre indisciplinaire qui y a eu lieu.

DHC/ART is a non-profit organization dedicated to the presentation of contemporary art. Ongoing annual programming includes two to three major exhibitions, a series of public events, special collaborative projects and educational offerings geared to learners of all ages and experience with contemporary art. DHC/ART's mandate emphasizes programming that is international in scope while responsive to the context of the city of Montreal. All of DHC/ART's programming is offered free of charge as a way to reinforce its commitment to accessibility while fostering a discussion on how contemporary art is invested with the topics and ideas that reflect and touch our everyday lives ${ }^{2}$. 
Facilitated in a spirit of dialogue, a guided visit at DHC/ART is an opportunity to discover, question and reflect on contemporary art with others. Guided visits are adapted to the needs and interests of those participating. Our approach is grounded in the phenomenology of movement and critical thinking informed by diverse perspectives.

Pohanna Pyne Feinberg: Activities and admission that are free of charge and a building that considers reduced mobility are important first steps in making the Foundation accessible to diverse visitors. The notion of accessibility also expands to providing a context that opens up the very notion of movement to include the physical, the emotional, the intellectual; where experiencing art and asking questions can occur with freedom of thought and expression. How does the DHC/ART Education team provide this kind of context?

Amanda Beattie: The ideas that you introduce in your question are really interesting and important to us: accessibility, movement, experience. In order to fully speak to these ideas, we need to first back up and discuss how our working methodology relates to our work with groups in the galleries. The Education department is co-coordinated by the four of us; in addition to gallery teaching, we facilitate workshops, create pedagogical tools, develop partnerships, organize public programming, and do ongoing administration in support of the department's mandate. This is a different model than others I have experienced working in larger institutions like The Museum of Modern Art (MoMA) in New York and the Montreal Museum of Fine Arts (MMFA), where the role of the educator is very specific: to bring groups through the exhibitions and lead art workshops. At DHC/ART we are responsible for every step along the way, from conception to delivery. The work environment is also extremely important: everything that we do as a small team is non-hierarchical, shared and in an environment of mutual respect.

PPF: So, your collaborative approach influences how you interact with the public. How did this environment of mutual respect come to be?

\section{$A B$ : I would say organically. There was a vouloir partagé.}

Marie-Hélène Lemaire: Puisque nous sommes tous arrivés en même temps pour former une nouvelle équipe, il y avait une sorte de liberté d'expérimenter pour développer le département à notre façon.

Daniel Fiset: À notre arrivée au département d'éducation, il y avait déjà un réseau de contacts dans le monde universitaire et communautaire qui avait été établi, en plus d'une structure solide avec des projets publics, des ateliers et des visites-discussions. L'objectif était de continuer à développer le département en prenant en considération les efforts déployés par nos prédécesseurs.

$A B$ : Right away we began to build on what was already in place. And although we all came from different backgrounds, we shared a common 
interest in a certain kind of museum education-and a certain way of working. Another important factor is our very close relationship with curatorial-excellent communication, support and a shared desire to work together. This collaboration encourages initiative, the development of new ideas and a really stimulating environment to work in.

PPF: Benefiting from this freedom within the structure of the organization as well as an open dialogue with the curatorial team, would it be true to say that your initial intention was to experiment by working together and developing your own method?

Emily Keenlyside: I think so. I understood from the beginning that we were each bringing something unique to $\mathrm{DHC}$ - be it past experiences or other projects-that would nourish the work and the team. Early on our curator Cheryl Sim made another important point that informed how I approached my work with both the public and with all of you. She stressed the importance to her of service, telling me she regularly asked herself How am I of service? This question(ing) resonated with me because while doing my MA, I thought a lot about service. This reflection was challenged and nourished by the work of feminist writer and activist bell hooks who explained how service, in a contemporary context of white imperialism, is perceived as an act of subordination. By contrast, hooks considers an educator's service to be an act of kindness that demands responding to students' needs and honouring their will to learn ${ }^{3}$. So hearing Cheryl's words, I thought to myself, I'm in the right place. This isn't an education department that is detached from the diversity of experiences that people are going to bring to an exhibition. Rather, it seeks to create spaces where people exchange, where facilitators are conscious of power, of diverse perspectives, of potential conflict.

PPF: After five years of sharing in reflective symbiosis, I imagine your collective approach has become well developed. In practical terms, what does it look like? How do you prepare your educational programs?

$A B:$ We talk a lot! We exchange ideas, experiences, questions, and solutions. We brainstorm. And we each bring something different to the table.

MHL: Oui, nous échangeons beaucoup, de manière ouverte, improvisée et créative. À cet effet, mon expérience antérieure en tant qu'éducatrice au Musée d'art contemporain de Montréal m'avait laissée obsédée par cette idée de Marcel Duchamp: «the creative act is not performed by the artist alone: The spectator brings the work in contact with the external world, deciphering and interpreting its inner qualifications, and thus adds his contribution to the creative act ${ }^{4}$ ». Pour moi, n'ayant pas de formation universitaire en arts visuels ou en histoire de

3 HOOKS bell. Teaching Community: A Pedagogy of Hope. New York and London: Routledge, 2003, p. 97.
4 DUCHAMP Marcel. "The Creative Act ". Art News, vol. 56, n 4,1956 , p. 29. 
I'art, cela implique que tous et chacun, nous pouvons interpréter l'art contemporain en puisant dans notre expérience personnelle. Donc, préparer les visites de groupe dans les expositions implique cette réflexion: comment puis-je créer un climat dans les espaces de DHC/ $A R T$ où mes collègues, les participants à mes visites de groupe, ainsi que moi-même, nous pouvons avoir accès à cette profonde créativité, en collaboration et en dialogue, lors de notre interprétation de l'art contemporain?

Lors de mon doctorat à l'Université Concordia, j'ai appris sur la méthodologie des concepts migratoires de Mieke Bal et cela représentait pour moi une manière concrète de mettre en œuvre cet acte de création en communauté dans la réception de l'art. Les concepts migratoires ont une dimension résonante et vibratile qui interpelle les corps en mouvement et une dimension analytique qui s'adresse à I'intellect ${ }^{5}$. Chaque fois que nous concevons notre programme éducatif pour l'exposition à venir, nous faisons tout d'abord un brainstorm où chacun de nous contribuons avec nos concepts migratoires pour créer une grande constellation de concepts partagés, ce qui cristallise la forme que prendra notre programme éducatif.

PPF : A constellation—could you explain that a bit more?

MHL: L'interprétation en mouvement de l'exposition d'art contemporain, c'est une sorte de voyage dans des espaces ouverts, imprévus, expérimentaux, même obscurs et déstabilisants. Dans ce type d'espaces, les concepts migratoires nous guident en formant des constellations; c'est en fonction des idées apportées par les participants lors de la visite que certains concepts ressortiront pour être élaborés davantage, alors que d'autres resteront dans l'ombre, temporairement. Ces configurations éphémères mises au jour par les visiteurs, j'y réfléchis en post-visite par ma pratique d'écriture créative de fiction; celle-ci me permet de jouer avec les dialogues qui résonnent en moi pour inventer à partir de ceux-ci. Cette pratique d'écriture créative et analytique, au sens où l'entend Laurel Richardson ${ }^{6}$, me vient de ma formation en littérature et en communication.

PPF: That's a helpful word-encouraging a playful environment seems beneficial to considerations of accessibility.

EK: I think we can all agree that play doesn't have to rest on the surface of things. One can engage quite deeply in play, with something playful.

AB: Paula Scher, a graphic designer based in New York, has spoken

5 BAL Mieke. Travelling concepts in the humanities: A rough guide. Toronto: University of Toronto Press, 2002.
6 RICHARDSON Laurel. "Writing: A method of Inquiry ". Norman K. Lincoln and Yvonna S. Lincoln (eds.). Handbook of Qualitative Research. Thousand Oaks: SAGE Publications, 2000, pp. 923-948. 
about the distinction between serious play and solemn play. Serious play is play that is experimental and exploratory. It's when you jump into something and you don't really know where it's going to go, you're a little bit out of your comfort zone, and that's where some really interesting things can happen. Solemn play is your everyday, it's the expected-you know what you're doing, you know what's expected of you. You've done it many times before and maybe you do it really well and really enjoy it, but there's less room for experimentation ${ }^{7}$. The idea of play-particularly serious play-is really important in creativity and development. It also has an important place in pedagogy, and in keeping ourselves-our practice as both teacher and learner-relevant and updated and fresh.

MHL: Ce que tu dis Amanda fait écho à une expérience d'écriture fondatrice où j'ai rédigé un récit fictif auto-ethnographique à la suite d'une conversation que j'avais eue avec une collègue. Écrire ce texte a été un moment de pur jeu et de pure liberté qui a eu un effet profondément transformateur pour moi à un moment où j'étais une jeune pédagogue/étudiante doctorale. Plus récemment, Sylvie Colucci, une de nos partenaires enseignante de $5^{\mathrm{e}}$ et $6^{\mathrm{e}}$ années du primaire, nous a dit avoir demandé à ses élèves de décrire comment ils se sentaient à $\mathrm{DHC} /$ ART. L'un des mots importants qui est souvent ressorti était la liberté. Les enfants disaient se sentir libres à la Fondation: libres de mouvement dans les espaces, libres de s'exprimer de manière spontanée et ouverte, sans qu'il y ait d'attentes ou de jugements par rapport à ce qu'ils devaient dire. Et pour cette enseignante, il est très important que les enfants se sentent vraiment écoutés, car cela leur donne confiance en eux, et ils éprouvent ainsi un plaisir croissant dans cette interprétation créative et dialoguée des œuvres ${ }^{8}$. On voit ici se déployer la valeur de liberté, qui est cruciale pour notre directrice Phoebe Greenberg, en lien avec la notion de dialogue, qui est aussi pour elle très importante.

PPF: I can relate to that. I also appreciated a sense of freedom while working with the Education team in the past. My impression is that these notions of freedom, open dialogue, and service with care emerge at the very start of your planning process. How does it feel to be in that brainstorm? And how do you approach it?

DF: I suppose the word that comes to mind is anticipation. You've been accumulating personal knowledge about the work because you're reading so much about the artist and the context, and you're building up this inventory of possibilities that you're then invited over the span of a few hours to exchange, and then you are reminded that the thinking that you do alone is not in total isolation, and that the concepts that you think are important are also important to other

7 SCHER Paula. Great Design is serious, not solemn [Video file], <https://www.ted.com/talks/paula_scher_gets_serious/ transcript?language=en $>$, consulté le 20 février 2017.
8 DHC/ART Foundation for Contemporary Art. Voir plus loin: un entretien avec Sylvie Colucci [Audio file], <http://dhcart.org/blog/2017/03/08/voir-plus-loin-un-entretien-avecsylvie-colucci/>, consulté le 10 mars 2017. 
people; that is the most gratifying thing in the process. And that carries out into the visit because that realization is also something that you can do with a participant. You might not come to the idea the same way, you might not express it in the same manner, but in the end you are sharing a concept. In all steps of our process leading up to reaching the groups it's very important to be free to share and think and contrast some ideas because it is going to make it so much easier to be that free in the visit. If you hit too hard on the points you want to make and you don't leave any room for overlap you're directing the visit rather than facilitating it.

EK: I agree. Engaging people to respond to each other. So whether an idea challenges or resonates with participants, how can we effectively facilitate this experience of thinking, talking, and listening between people around a work of art?

\section{CASE STUDY I}

Artiste visuel britannique d'origine nigériane, Yinka Shonibare MBE utilise le tissu wax comme matériau premier de ses œuvres. S'il est parfois compris comme stéréotypiquement africain, ce textile résulte d'une appropriation coloniale occidentale des techniques traditionnelles du batik indonésien, techniques dont la production a été industrialisée en Europe pour la revente en Afrique. Le wax est alors un vecteur pour réfléchir à l'identité, l'authenticité, l'ethnicité, la représentation, l'hybridité, la race, la classe sociale, la migration, la mondialisation et le pouvoir.

The Sleep of Reason Produces Monsters est une série de cinq épreuves chromogènes réalisées par Shonibare, qui sont inspirées d'une gravure du même titre de l'artiste espagnol Francisco Goya. Sur chacune des images, on voit un homme, tête penchée sur un bureau, entouré d'un groupe d'animaux nocturnes qui gravitent autour de lui. Chaque photographie porte le nom d'un continent, intégré dans une citation gravée sur le côté du bureau. L'œuvre est une charge contre l'exploitation coloniale, qui subvertit les codes visuels des Lumières pour rappeler les pans sombres de cette époque. Lors de la visite animée avec les participants de la journée indisciplinaire, nous avons pris la décision de diviser les visiteurs en sous-groupes pour permettre des conversations plus intimes. Il était important de réfléchir à l'actualité du propos de Shonibare, au-delà de son inscription dans l'histoire occidentale. Au delà d'une reconnaissance de la citation, est-il possible de retourner à une lecture plus immédiate de la proposition de Shonibare? L'efficacité critique de l'œuvre de Shonibare dépend-t-elle d'une prise de conscience du matériau de l'histoire de l'art que l'artiste vient s'approprier et trafiquer? 


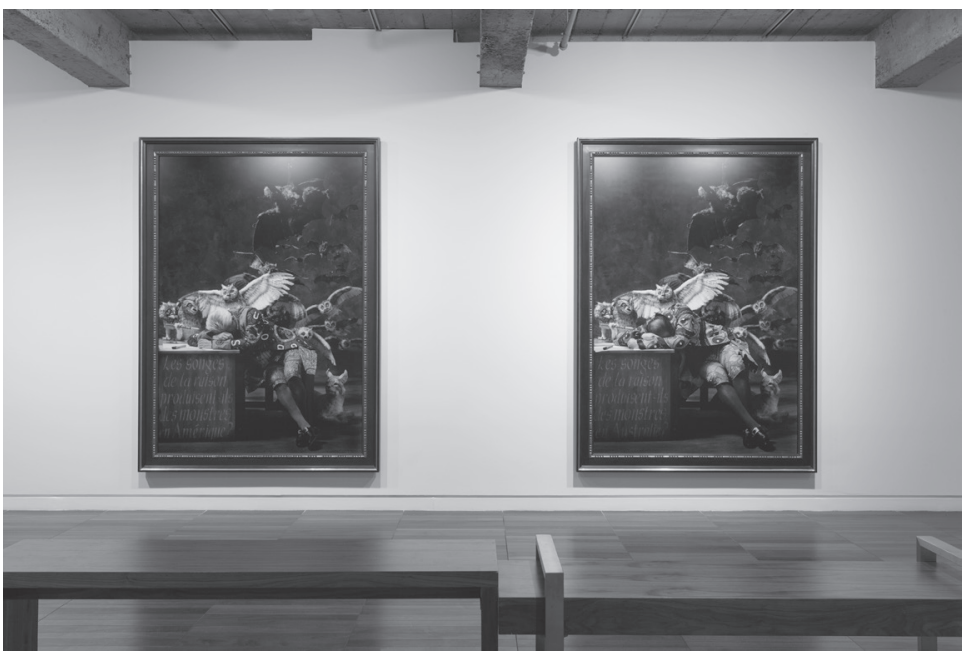

Vue de l'exposition Yinka Shonibare MBE: Pièces de résistance, 2015, DHC/ART Fondation pour l'art contemporain, Montréal. De gauche à droite: The Sleep of Reason Produces Monsters (America), 2008; The Sleep of Reason Produces Monsters (Australia), 2008. Photo: Richard-Max Tremblay.

View of Yinka Shonibare MBE: Pièces de résistance, 2015, DHC/ART Foundation for Contemporary Art, Montreal. Left to right: The Sleep of Reason Produces Monsters (America), 2008; The Sleep of Reason Produces Monsters (Australia), 2008. Photo: Richard-Max Tremblay.

DF: Pour faire un lien avec la question du type d'expérience que nous cherchons à concevoir autour de l'œuvre d'art, je dirais que ma formation $\mathrm{m}$ 'avait habitué à autre chose. J'ai étudié exclusivement en histoire de l'art au baccalauréat et ensuite à la maîtrise. J'ai ressenti alors une certaine frustration des limites de l'enseignement traditionnel universitaire: les conversations sont cadrées, il y a ces relations de pouvoir entre les enseignants et les enseignés. Venait alors le désir d'avoir un espace plus libre où l'on peut concevoir et essayer des choses, ouvrir des conversations sur les œuvres. Dans mes études en histoire de l'art, on traitait peu d'éducation à l'art et de théorie sur l'éducation. En fait, DHC/ART était ma première expérience professionnelle dans le domaine de l'éducation muséale. C'est le début d'une réflexion sur les possibilités d'une histoire de l'art et d'une éducation muséale plus inclusives, ouvertes, responsables, qui visent l'empowerment, l'agentivité, la construction d'une confiance du visiteur par rapport à ses capacités à interpréter et à comprendre le monde qui l'entoure.

EK: That really speaks to me. I came to DHC after a decade of straddling museum education and community work and have for a long time thought about the ways in which questions of community and inequality intersect with visual culture. Very early on in my studies I was taken by popular education, participatory learning, and critical pedagogy, inspired by educators like Paulo Freire, Robert Chambers, Henry Giroux - writing that considered the conditions under which transfor- 
mative, potentially liberating learning can take place, learning that is reflected in participants' everyday lives. The kinds of spaces that best engage people to express themselves and challenge each other. In the context of DHC/ART Education, this starts with each other.

$A B$ : Our working relationship is one that is very dynamic and alive, and we try to bring those feelings to our visits-to encourage expression and empowerment, as Emily mentioned. I also wanted to go to back to something that Daniel mentioned earlier-the idea of anticipation as we prepare for our visits-as it is really an example of one way that we prepare for facilitating exchanges in the gallery. There's a kind of buzz during our collective brainstorming sessions about themes that we will expand on for our visits and our pedagogical tools. It's a very active and animated brainstorm. At times we'll stop to clarify a term and unpack its meanings. And then, these concepts make their way into the gallery and to our groups, and it's this magical experience, where a group of people are getting excited about ideas. It brings our initial ideas into a different reality. They become alive, in a way-they take on a life of their own when they are discussed from different perspectives.

MHL: Cette pensée emplie d'affect et de vitalité pointe vers un autre élément important de notre pratique: l'idée de " penser en mouvement ", notion définie par Maxine Sheets-Johnstone, théoricienne en sciences cognitives et en phénoménologie de la danse. Selon cette perspective, la cognition prend racine dans notre corps en mouvement et dans notre sens tactile-kinesthésique, ce qui nous permet d'acquérir une connaissance sur l'art connectée sur l'animation de notre expérience vécue?

DF: La liste de concepts qu'on développe reste sur le tableau blanc tout au long de l'exposition... c'est une carte, en fait, qu'on revoie souvent dans notre quotidien. À partir des concepts choisis, on a aussi une pratique d'écriture qui se déploie dans Mouvements, un outil pédagogique qui est ensuite partagé. II y a donc initialement un travail de mise en commun, puis ensuite un moment d'écriture personnelle. II y a donc toujours un va-et-vient entre l'individuel et le collectif. Cela veut dire que les concepts sur le tableau nous servent d'aide-mémoire, un outil visuel. De les voir écrits comme ça, ça aide beaucoup, ça devient matériel, tangible.

EK: Throughout this process we recognize that more concepts will emerge. I think it is important to stress that identifying key concepts is not a strategy to pre-determine what it is that we are going to talk about in the galleries. Rather, it informs our initial understanding of the work, which serves as a starting point. When creating pedagogical tools we may focus on selected concepts but when we are facilitating, content is never the same from one visit to the next. These concepts 


\section{SHONIBARE - PIElCS de RESIStance}

AMBURLENCE MIGRATION SATIRE REPETTTION

EXLESS CARNAUALESQUE DUTCHWAT PLEASURE TIME ENUGTHENMENT COSDMUE FETSH BEAUTE HYBRIDITE FASHION DANDYLETSURE SÉDNCTION MASQURADE DISABLITYAMBIGUITE TEXTILES FAKE THEATRICALITY COMTAMINATION FABRIC APPROPRIATIION ORIGINS INEQUPLITY AUTHENTICITY MUBILITE PRIUILETE RESISTANCE VICTORIAN HISTORY CLASS TRANSFORMATION POWER ETHNICITZ IDENTITY CONTRADKTION COCONIALISID MORAUTM EXOTIC SUBUERSIVE POSTCOCONIAUSM MATERIAUTIG ALIEN DELADENCE DECOLONIAL STERCOTJPE PERIPHERIEBATIK NEOCOLOMIAL EXAGGERATION FICTION ACCUMULATION IRONIE PDLITLS OF REPRESENTATION FraGMENTATION décadenLE IR/RATIONAL FrIVOLITÉ POLITICS VALUE ASSIMILATION ART HISTORY CIUILISÉ PRIMITUUE RELATION CONTEXTE-MIGRATTON

COMPOSIIION - PLAISIR CONTENU - RCZATION CONSIDERATIONS - DANDY

\section{DHC/ART Éducation}

guide us, but ultimately we may or may not touch on them - because it is always about what the visitors are bringing to the exchange. This speaks to Burnham and Kai-Kee's work on dialogical learning ${ }^{10}$; it is not pre-determined, we don't have a set of learning objectives that we expect people to achieve, we are open to what happens, and we never really know the direction that a guided visit is going to take. Committing to dialogue makes it riskier for us but much more engaging for everybody. 
$A B$ : I was just going to expand on the word "open". It is so key to the way that we work together and what we bring to the exhibitions. At the start of a visit, for example, we will invite the group to move around on their own so that they can have a few moments with each work and fill their senses. Then we will generally ask them where they want to start, and what grabbed their interest. This is a freedom that is not always possible in other museum visits, for a number of reasons. I think that it gives ownership to the visitors and makes them feel comfortable and confident.

PPF: I am considering this sense of risk, openness, and freedom that you first experience as a team and then bring to your group visits. Aren't there surprises and challenges related to this approach?

$A B:$ I think adaptability is the main thing. Sometimes, the approach that we plan on taking with a group might not work. If this is the case, the important thing is for the educator to read the group and see what works for them. If they need more independence in the gallery space, or less discussion time, that's okay. The benefits of this approach that we have been discussing definitely outweigh the challenges!

At MoMA, I worked in the Community and Access program where we had programming for people who are blind, or partially sighted people, people who are deaf, people who are autistic, and individuals with Alzheimer's disease and their care partners. At the MMFA and the Peggy Guggenheim in Venice, I worked mainly with kids. Adaptability is necessary for all the various publics I've worked with. For the past five years I've taught art history to CEGEP students, who are probably our biggest public here at DHC. It's been really interesting to go back and forth between the gallery and the classroom setting, each with their own particular dynamic. I've gotten to know this public better-what works for them, what interests them, what catches their attention. And also what their abilities are and what level we should be aiming for with this particular group.

EK: And of course recognizing the diversity that exists within these various publics. So adaptability means getting to know them, responding in the moment, and being open from the get go.

DF: No matter what, you are still providing the group with some potentially very essential things : shelter, rest, a space where they can move around, where they feel free to talk... amongst themselves ....

$A B:$ an experience...

DF: ... an experience, so sometimes it is also about, I find, letting go of your own expectations of what an ideal visit is and understanding that you are also there to serve needs, and the needs vary constantly, and it is your responsibility to try as much as possible to meet these needs so that everyone feels at the end of the experience that they were welcomed and comfortable and felt free. That sense of freedom, to 
say: "it is OK to disperse, talk amongst yourselves", it is not a type of learning that is encouraged, but it is so primordial to get them to talk amongst themselves and share...

PPF : ... to encourage these types of open conversations, where participants are free to improvise, can also allow space for more informal comments on the side between a few people. These impromptu connections can offer great insight.

$A B$ : There is also room for silence during our visits. To us, silence can be an indicator that people are thinking, absorbing, processing, and whether they have something to share afterwards or not doesn't really matter. What matters is the process, and that people are being offered the opportunity to take a moment of pause and reflection. There is also the question of building a relationship with a group, and sometimes that takes time. Architecturally, this works really well at DHC/ART! On the first floor, visitors are just getting an introduction into the relationship that is being built; on the second floor, people begin to open up more; by the third floor, there is usually a common understanding of group dynamics, and so on and so forth.

PPF: So it is useful to understand points of access as progressive rather than immediate-and coming to an interpretation of the art works is something that is cultivated through on-going movement and through various interactions...

EK: Yes. Three of the four of us come from large museum environments where the galleries are often so vast that this idea of leaving people to circulate on their own, even for a few moments, is much more of a challenge logistically. This comes back to Amanda's earlier comments; here the parameters of the galleries are small, allowing for this contained movement, or these contained silences.

MHL: Intimacy.

EK: Yes, intimacy. The educator and the architecture together can offer a kind of-we don't have the word in English that I'm looking forencadrement. This support is something our predecessors in Education described as well. It is an important part of our facilitation, which engages with that freedom of talking, not talking, moving, not moving, together, not together.

$A B$ : Another important factor is that contemporary art is generally very open, in that it allows for and often even invites multiple interpretations. Visiting an exhibition as a part of a group offers a really rich opportunity, as everyone is invited to share their thoughts and all comments are valid and welcome. Having said that, a lot of the work that we deal with can be extremely intense, heavy, and emotional. The works can be challenging to look at in some cases, or introduce ideas that are difficult to think about. The approach that we've been describing (allowing for silence, inviting any comments...) is particularly 
beneficial for people when they are dealing with works that may be about violence or other difficult themes...

DF : ...exploitation, colonisation...

MHL: Oui, les œuvres peuvent être difficiles, tout comme l'architecture de la galerie. Car, pour faire écho à Emily, nous avons la chance ici d'avoir des espaces intimes. Toutefois, l'espace de la galerie ou du musée d'art, même à la Fondation, n'est pas un espace neutre. Quand on y entre, l'architecture même a un effet sur le corps. Ce dernier se discipline, devient docile. Aussi, quand on invite les participants à la visite à émettre des paroles improvisées, il ne faut pas oublier que ces voix sont dévaluées par rapport à la théorisation des œuvres qui se fait par l'écriture, que ce soit par le texte d'introduction à l'exposition au mur ou par les catalogues. Les paroles échangées en visite sont interrompues, hésitantes, quelquefois trop faibles. Ce n'est pas nécessairement confortable. Il y a là une relation de pouvoir qui se joue ${ }^{11}$. Donc, nous éducateurs, on cherche à créer une « bulle » en visite, un espace qui favorise l'expression de la parole et des corps et qui cherche à amenuiser les effets disciplinaires du Cube blanc.

\section{CASE STUDY II}

Nelson's Jacket is Shonibare's appropriation of an object on permanent display at the UK's National Maritime Museum—a jacket that was originally worn by Admiral Horatio Nelson at the Battle of Trafalgar. Nelson's Ship in a Bottle (maquette), refers to the public commission Shonibare produced for the fourth plinth in London's Trafalgar square in 2010. Both are scaled-down replicas of Nelson's flagship HMS Victory, adorned with Dutch wax sails and referencing Nelson's Column, an almost 60-metre granite monument erected in the Square between 1840 and 1843.

The allegory of Nelson as a starting point allowed us to situate the works locally, since less than a kilometre from DHC/ART stands another Nelson's Column. Located at the top of the gentle slope of Place Jacques Cartier, not far from the St. Lawrence river, the original figure was erected in 1809-a mere four years following the battle that famously halted Napoleon's forces and further paved the way for British imperialism. Homages to colonial ambition, both this monument and its surrounding public space, served as fertile ground to take our reflections on the Shonibare exhibition beyond the gallery walls-to 
engage directly with the dominant narratives that shape our cityscape, looming over Old Montreal and, indeed, our collective consciousness. In the spirit of the visite dé-guidée, Dominic Hardy and students Giuditta Lorenzini and Daniel Boisclair led us, through works of original fiction, on an extended exploration of the spaces and histories between Shonibare's works and Montréal's oldest public monument. How do historical events relate to contemporary experiences of space? How has colonial violence shaped the fabric of our cities?

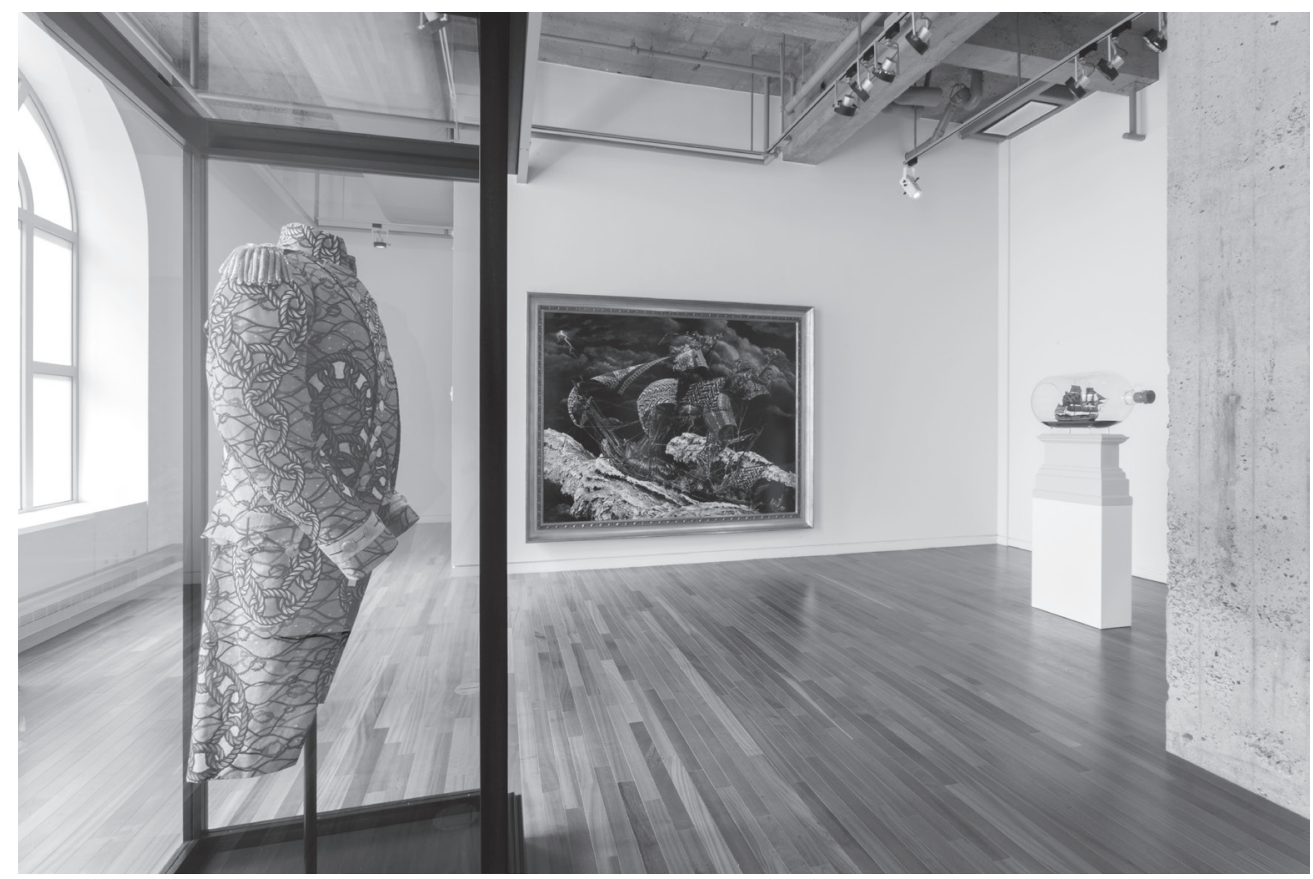

Vue de l'exposition Yinka Shonibare MBE: Pièces de résistance, 2015, DHC/ART Fondation pour l'art contemporain, Montréal. De gauche à droite: Nelson's Jacket, 2011 ; La Méduse, 2008; Nelson's Ship in a Bottle (maquette), 2007. Photo: RichardMax Tremblay.

View of Yinka Shonibare MBE: Pièces de résistance, 2015, DHC/ART Foundation for Contemporary Art, Montreal. Left to right: Nelson's Jacket, 201 1; La Méduse, 2008; Nelson's Ship in a Bottle (maquette), 2007. Photo: Richard-Max Tremblay.

$A B$ : Even a small gesture like inviting people to sit down on the floor can make a difference. We all know that a visit that is an hour and a half long can get tiring for the body—no matter how engaged one is! Just the act of inviting people to sit introduces less formal behaviour than one might expect for a gallery setting. It also tends to bring people together-especially when we can sit in a circle and the educator can sit down as well. 
PPF: Yes, there is this way of welcoming groups that makes it clear that the visit is about points of departure, or about planting seeds or raising questions, and that it is not necessarily an easy process. Yes it can be playful, yes it can be an exciting exchange, and it can also be difficult work.

\section{$A B$ : And difficult is OK...}

PPF: Difficult is OK, and when considering the word "inclusion" or "accessible"; acknowledgement that each visitor is encouraged to react honestly is important.

EK: Certain key concepts shape how we mediate exhibitions with our groups; Daniel mentioned one of them already: agency. Another is authenticity, which Amanda often speaks about. These two concepts guide our interactions with the people who are in the galleries with us.

DF: My encounter with the concept of agency is very much informed by its use in feminist and queer theory. Agency, to put it simply, can be understood as each individual's capacity for self-determination, to enact a choice. In the museum context, I see it as a tool for shedding some of the instilled power dynamics between learners and educators, which can enable us to develop a dialogue based on freedom of choice and critical thinking.

PPF: And when you say "authentic", what does that mean to each of you?

EK: An authentic educator is a true listener. There is a passage by Nina Simon in her first book The Participatory Museum that made me laugh out loud because it was so simple and yet so key-and sadly rang so true. She states that anytime you ask a question you should have a genuine interest in hearing the answer. ${ }^{12}$ This again goes back to our working methodology and how we expect the values that drive it to be mirrored in the galleries. The very deliberate act of listening; you care about what people are doing, what they are saying, and also what they are not doing, not saying. For me this is as much political as it is interpersonal.

$A B:$ I think a big part of being authentic is that we are present. We are not just there to get the group through the whole show and get out of there. We are present with the groups, we have a genuine interest in the visitor's' thoughts, experiences, and what every individual can bring to the shared experience. Being honest is another important elementpeople can tell if someone is truly engaged, or just going through the motions.

DF: Part of that is learning to cope with the absurdities of the art world, to expose them and to unfold them in dialogue. I've been a cultural worker for some time now, and I've enjoyed working in this field, but 
there are a lot of strange things going on in the art world. A lot of things that don't make sense when you are outside of it (or even when you are inside of it): certain distributions of power or unnecessary hierarchies...

$A B: \ldots$ the art market

DF: Right, the art market. In that regard, our aim should be to create spaces or moments in the visit where people are free to encounter the absurdities of that world and truly reflect on them. That means to not flat-out dismiss the idea of art, and say "I am not interested, this seems absurd, ridiculous" - but to engage profoundly with what it is that bothers them about a work being potentially absurd or strange or off-putting or limited. Some of the visits that I've truly enjoyed are the visits where you feel an initial resistance to the content, to what they are seeing. It is an effect that is very powerful and it accompanies you throughout the exhibition. At a certain point there is an accumulation on the part of the visitor and there is a kind of burst, an "aha" moment. It is that recognition that there is something: that there is a supplementary knowledge of a system being brought to the forefront, when a person acknowledges that there is something that doesn't work for them. To address that in a group is really powerful. This is also part of what being authentic means: it is not just agreeing completely with everything that is happening in the field or the sector that you work in, just saying: "oh, no, no, that's not a problem, not a big deal...

$A B$ : that is just how it is...

DF: that is just how it is"—excusing it as natural, when it isn't. I'm reminded of a Luis Camnitzer quote: "one cannot educate properly without revealing the power structure where education takes place. Without an awareness of this structure and the way it distributes power, indoctrination necessarily usurps the place of education"13. Otherwise, you become a parrot, someone who's main role is to repeat content and reinstate power dynamics within the dialogue. It is another kind of liberty that you don't often have as an educator: to be able to get to address these questions in a gallery context.

EK: Sylvie, the teacher Marie-Hélène referred to earlier, shared an anecdote with us that I think speaks to what you are saying. A student walked in one of the galleries and basically said-and here I am paraphrasing her paraphrasing him: "If I were the person who decided where the artworks go, I really wouldn't have done it like this. I would have put that like this, or that like this. It would make more sense"14. It is so important to allow a 12-year-old to question curatorial choices; you are not going to shut that kid down and say: "well, these were deli-

13 CAMNITZER Luis. "Art and Literacy ».e.flux. Journal \#03 - February 2009, <http://www.e-flux.com/journal/03/68519/art-and-literacy/>, consulté le 24 février 2017.
14 DHC/ART Foundation for Contemporary Art. Voir plus loin: un entretien avec Sylvie Colucci [Audio file], $<$ http://dhcart.org/blog/2017/03/08/voir-plus-loin-un-entretien-avecsylvie-colucci/>, consulté le 10 mars 2017. 
berate choices made by a professional "... of course they can challenge them—and they might even be right.

DF: Yes, that means challenging our expertise as educators which is sometimes very destabilizing, but fine ultimately,

MHL: Oui, être authentique comme pédagogue, c'est laisser cet élève remettre en question à la fois l'expertise de la commissaire, de l'artiste et la nôtre, et l'accompagner à clarifier et à approfondir sa pensée à ce sujet; pour lui donner la liberté non seulement de remettre en question les choix de la commissaire, mais pour proposer quelque chose d'autre, de manière complémentaire, constructive, dans un esprit de dialogue et d'agentivité partagée encore une fois.

\section{CASE STUDY III}

The Age of Enlightenment - Immanuel Kant fait partie d'une série d'œuvres où Shonibare représente diverses figures emblématiques du Siècle des Lumières. Ici, le philosophe Kant est représenté avec une couleur de peau brun pâle, un habit typique de l'homme savant du $18^{e}$ siècle européen, en tissu wax, sans jambes et sans tête. Ainsi, l'artiste évoque le fait que si les idées des Lumières ont mis de l'avant la force de la raison chez l'individu, celui-ci était eurocentré et masculin, et cela a justifié la conquête et la domination coloniale des peuples dits " primitifs " avec, pour objectif, la mission de civilisation. Aussi, si le tissu wax représente souvent, à tort, une pure et authentique africanité, il est en fait hybride. Lors de la journée indisciplinaire, Myriam Suchet a discuté de la traduction du roman The Voice du poète nigérian Gabriel Okara, afin de contribuer à la réflexion autour de The Age of Enlightenment. The Voice raconte la quête d'un jeune homme, Okolo, de quelque chose $d$ 'indéterminé, désigné par « It ». Considérant cette quête comme subversive, les habitants et les chefs du village condamnent ce personnage à mort. Okara, qui a écrit ce roman en anglais, et non dans sa langue maternelle l'ijaw, considère que l'anglais est une traduction quasi littérale de l'ijaw. Suchet remet en question cette conception d'une voix unique comme source du texte en analysant la traduction du roman d'Okara en français et en allemand. À son avis, plutôt que de retracer la parole initiale d'un énonciateur unique et authentique, le traducteur en est le porte-parole, il parle au nom d'un autre, mais en conservant sa propre voix, produite par le texte qu'il a traduit - voix traversée par plusieurs autres voix ${ }^{15}$. Ici, nous sommes donc dans une conception

15 SUCHET Myriam. "Observations comparées d'un traduisible: « Inside " dans The Voice d'Okara, La voix de Jean Sevry et Die Stimme d'Olga et Erich Fetter ». Dans DÜNNE Jörg, Martin Jörg SCHÄFER, Myriam SUCHET et Jessica
WILKER. (éds). Les intraduisibles : langues, littératures, médias, cultures, 2013, Paris: Éditions des archives contemporaines, p. 133-143. 
hybride et polyphonique de l'acte de traduction, en écho aux idées d'authenticité et d'hybridité que Shonibare nous propose avec The Age of Enlightenment. Shonibare représente Kant sans tête et sans jambes, pourquoi à votre avis? Les penseurs des Lumières valorisaient une forme de pensée axée sur la raison. $\mathrm{Si}$, pour mettre au défi cette position, nous explorons les formes de pensée autres, de quelle manière peuvent-elles enrichir notre façon d'entrer en relation avec le monde?

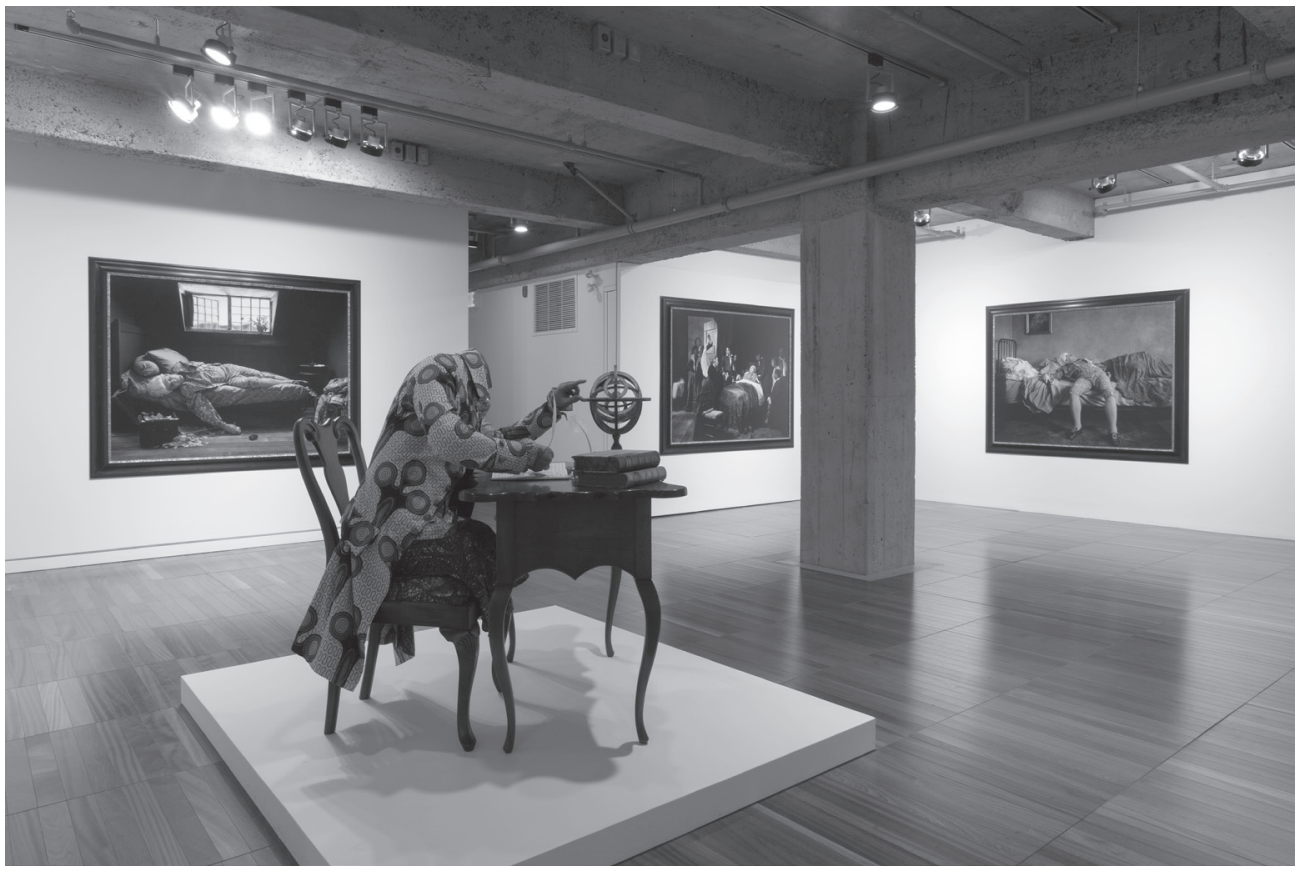

Vue de l'exposition Yinka Shonibare MBE: Pièces de résistance, 2015, DHC/ART Fondation pour l'art contemporain, Montréal. Premier plan, deuxième plan, de gauche à droite: The Age of Enlightenment-Immanuel Kant, 2008; Fake Death Picture (The Death of Chatterton-Henry Wallis), 2011 ; Fake Death Picture (The Death of Leonardo da Vinci in the Arms of Francis I-François-Guillaume Ménageot), 2011 ; Fake Death Picture (The Suicide-Manet), 2011. Photo: Richard-Max Tremblay.

View of Yinka Shonibare MBE: Pièces de résistance, 2015, DHC/ART Foundation for Contemporary Art, Montreal. Front, back, left to right: The Age of EnlightenmentImmanuel Kant, 2008; Fake Death Picture (The Death of Chatterton-Henry Wallis), 2011; Fake Death Picture (The Death of Leonardo da Vinci in the Arms of Francis I-François-Guillaume Ménageot), 2011 ; Fake Death Picture (The Suicide-Manet), 2011. Photo: Richard-Max Tremblay.

MH: Et être ouverts à ce processus, cela nous permet de nous situer nous aussi et d'être toujours critiques et réflexifs quant à la nature de notre supposée expertise. Nous subissons nous aussi les forces de répression qui s'exercent dans le système de l'art. On nous demande comme pédagogue de posséder un savoir objectif très large... 
DF : ... de tout connaître instantanément...

$\mathrm{M}-\mathrm{H}$ : ...oui, tout à fait, ainsi, pour moi, intervenir de manière honnête, c'est aussi oser développer ma propre voix subjective, par l'écriture ou dans le dialogue. Si on demande aux participants d'oser s'exprimer subjectivement, il faut se commettre nous aussi, sinon la réelle écoute des autres est impossible. Et ce n'est pas facile. Si l'on cherche sa perspective unique sur l'exposition, ça semble tellement limité par rapport au savoir qu'on accumule en lisant les écrits des autres théoriciens et critiques d'art. S'engager à cela nous met dans une situation de tensions. On résiste à certaines forces du système de l'art qui nous veulent autrement, mais en même temps, on ressent ce plaisir, cette fameuse liberté dans l'écriture et dans la prise de parole avec les autres.

PPF : For me, authenticity is expressed in my sincere surprise during each visit. Each group responds differently to the works and I love this aspect of being an educator, the ever-expanding ways I learn about the art from the participants. With every insight, like you said Amanda, there is kind of magic that happens. These surprises can be both unsettling and joyful. They are always opportunities for me to learn.

On another note, given this intention to create a space of freedom for people to engage in conversations about and through art, have you developed relationships with local communities to help inform your capacity to provide an accessible space?

EK: Yes. And imagining new partnerships will only make our work stronger. I think we need to constantly revisit, question, and experiment with these notions that drive our mandate. So maybe we can finish by commenting on what that might look like? With partners, participants or each other? How do we want to grow?

DF: Le travail de l'accessibilité n'est jamais terminé. En fait, il est en constante évolution.

AB: As Emily and Daniel noted, accessibility is something that we are always considering and learning more about. We are always speaking to people and are open to new developments and new possibilities. For example, we have recently been looking into ways to make our spaces more accessible to our visitors with reduced mobility. This goes beyond the Education department and touches more broadly on the Foundation's goals as well. In general, I think that we can take our work further by reaching out to more people, more diverse groups, and continuing to promote the idea that contemporary art is for everyone. Pushing the boundaries is part of contemporary art, and is therefore a part of the work that we do as well. And this follows for the visitors too. They may be unaccustomed to our approach, the kinds of things that we are asking them to think about and to share...but that is what keeps things interesting, and that is where people learn the most! 
EK: I am really excited by Porchia Moore ${ }^{16}$ and a growing number of museum practitioners who are integrating intersectionality into museum discourse-how we need to think in terms of visitors' multiple and complex identities, and consider how what we do potentially renders people's stories or identities invisible. I think that we have a lot more work to do in that direction, especially as we talk about freedom. If accessibility is grounded in freedom, then how do we connect the work that we do with bigger questions of social justice and privilege? I don't think that they can be separated. I think being truly inclusive demands a willingness to change what you do and how you do it, and to give up some power in the immediate, short, and long term. So that's the challenge that I want to take on myself.

DF: Je confirme que l'idée d'intersectionnalité est très importante en fait et on doit s'y pencher sérieusement dans les prochains moments et aussi analyser comment ça se reflète dans notre propre méthode de travail. Également, je pense qu'une autre façon de créer des espaces $d^{\prime}$ 'ouverture avec les visiteurs, c'est de trouver d'autres manières d'expression, d'aller au-delà de l'hégémonie du langage, pour créer des espaces où l'on est libre de s'exprimer de façon distincte. On le fait déjà un peu par des exercices de mouvement, par des exercices de dessin. On le fait par l'atelier de création aussi... alors oui, c'est quelque chose que j'aimerais explorer encore davantage en fait.

PPF: Although it seems we could continue discussing these ideas for hours, perhaps I can conclude by rephrasing my initial question. Rather than ask how you provide accessible contexts where freedom of thought and expression are possible, it seems more appropriate to ask how you contribute to them as participants in an on-going dialogue with the artworks, with the visitors, and with community partners. Since openness to group dynamics and remaining adaptable are at the core of your process, your approach to accessibility could be well conceived within the framework of the travelling concept or concept migratoire. Rather than fixing it as a state to achieve, to be accessible is better understood as an ephemeral aspiration that is continually informed by insight through interaction. This interaction is a process of improvisation and experimentation that is grounded in the methods that you co-design and that enable your capacity as educators. For one, questioning the language that you use to convey ideas seems fundamental, as is recognizing that service can be found in the release of power. Authentic engagement in dialogue is practiced by remaining present during visits and listening carefully. By expressing trust in the value of embodied experience, you are inclusive of diverse modes of learning-somatic and intellectual. By welcoming disaccord as generative, you encourage agency in its various tones and from diverse perspectives. Appreciating the potency of quiet moments and varied formats for exchange during group visits also enriches the potential outcome of the dialogues. But,

16 MOORE Porchia A. "The Inclusive Museum 
as important is the time and space allotted for critical reflection (as a team and individually) which, as we see from this discussion, clearly strengthens your collective capacity.

And it really was such a pleasure to hear how you reflect together as a team, thank you! 


\begin{abstract}
DHC/ART is a non-profit organization dedicated to the presentation of contemporary art. Ongoing annual programming includes two to three major exhibitions, a series of public events, special collaborative projects and educational offerings geared to learners of all ages and experience with contemporary art. DHC/ART's mandate emphasizes programming that is international in scope while responsive to the context of the city of Montreal.
\end{abstract}

As DHC/ART Foundation for Contemporary Art approached its 10th anniversary, its Education team-Amanda Beattie, Daniel Fiset, Emily Keenlyside, and Marie-Hélène Lemaire — sat down with artist-researcher-educator Pohanna Pyne Feinberg to discuss their work. This onetime forum examined the particularities of their educational approach through a critical reflection on the past, present, and future of their work as gallery educators at DHC/ART, a parcours which began at the end of 2011. The following exchange highlights shared values grounding the Foundation's mandate; demonstrates the relationship between their work methodology and their mediation work in the galleries, and unpacks certain key concepts that shape this work.

Facilitated in a spirit of dialogue, group learning at DHC/ART is an opportunity to discover, question and reflect on contemporary art with others. Guided visits are adapted to the needs and interests of those participating. Our approach is grounded in the phenomenology of movement and critical thinking informed by diverse perspectives. Cet essai s'inscrit dans le cadre d'un partenariat que DHC/ART Éducation entretient avec des chercheurs universitaires autour des concepts de pensée en marche, de visite dé-guidée et d'indiscipline. En mai 2015, les éducateurs de DHC/ART ont été invités par Dominic Hardy (Histoire de l'art, UQAM) et Myriam Suchet (directrice du Centre d'études québécoises Sorbonne Nouvelle - Paris 3) à effectuer une journée de pensée en marche de l'exposition Pièces de résistance de Yinka Shonibare MBE (DHC/ART, présentée du 29 avril au 20 septembre 2015) dans le cadre de leur série de Rencontres indisciplinaires. La "pensée en marche", selon Suchet (2016), c'est la recherche qui sort de l'institution pour venir au musée, ce qui dynamise la réflexion théorique en dissertant avec l'œuvre plutôt que sur l'œuvre. Le format de la visite consiste à faire intervenir plusieurs chercheurs de différentes disciplines dans les espaces d'exposition du musée en présence d'un médiateur qui facilite les échanges avec le public. Nous proposons de réfléchir à Pièces de résistance de Yinka Shonibare MBE par l'entremise de trois études de cas tirées de la rencontre indisciplinaire y ayant eu lieu.

Throughout the conversation, we explore key concepts to our educational approach: accessibility, agency, authenticity, and freedom of thought and expression. These concepts are articulated through a framework informed by a plurality of methodologies and approaches: phenomenology, feminist and queer theory, critical education theory 
and communications theory, among others. Our approach to accessibility is nourished by Mieke Bal's travelling concepts. Rather than a fixed, achievable goal, we discuss accessibility as an ongoing engagement, an ephemeral aspiration that is grounded in reflexive practice and continually informed by insight through interaction. 